\title{
二次元キャビティ上の壁面噴流により 発生する流体音の受動的制御*1 Passive Control of Aerodynamic Sound Generated by Wall Jet over Two-Dimensional Cavity
}

\author{
池 田 敏 彦*2 ·松 原 雅 春 ${ }^{* 3}$. 阿 部 高 明*2 ·吉 田 尚 史*2 \\ Toshihiko IkedA, Masaharu Matsubara, Takaaki Abe, Takashi YoshidA, \\ 長 澤 忠 延*4.土 屋 良 明*3
}

Tadanobu NAGASAWA and Yoshiaki TsuchiYA

Key Words : Aerodynamics, Unsteady Flows, Control, Cavity, Wall Jet

\begin{abstract}
Control of a cavity tone has been done using triangle projections attached at an exit of two-dimensional jet. Experimental results of sound pressure level show that the projections obviously reduce both total sound pressure level and sound level of the dominant frequency of the cavity tone. The sound dumping effect is increasing with increasing number and/or height of projections though this dumping effect saturates with the certain number of projections at the nearly same sound level as that in the wall jet case. The spanwise distribution of pressure fluctuation at the downstream cavity edge has the minima at the right downstream position of the projections and at the other spanwise positions pressure fluctuation is homogeneously reduced. This result suggests that the mechanism of sound dumping is not only breaking two-dimensionality of flows.
\end{abstract}

\section{1. は じめ に}

噴流・エッジ系流れにおける噴流の発振現象と同樣に， キャビティ流れは自己励起型の振動流れの典型である . 作 動流体が空気の場合にはキャビティ音と呼ばれる流力騒音 が発生し，騒音源として周囲環境を悪化させる原因となっ ている．近年, 高速輸送技術の進歩はめざましい反面, 高 速化に伴いキャビティ音などの流力騒音問題がますます深 刻化してきている。

従来からキャビティ音に関して数多くの報告1 6) や解説・ 展望 7,8$)$ があり, 音の発生機構について一応の説明がなさ れている.

一方，キャビティ音の制御に関しては，光の工業的要請か ら近年いくつかの試みがなされている . 御法川ら ${ }^{9)}$ はキャ ビティ底面に取り付けたスピーカーによる能動的制御を試 みた . 制御信号として音圧変動の位相と振幅を調整して用 いることにより, キャビティ音を $-7 \sim 10 \mathrm{~dB}$ 増減すること に成功している .

Cattafesta ら ${ }^{10)}$ は低いマッハ数において , キャビティの 上流側角に取り付けたピエゾフィルムによるキャビティ音 の能動的制御を行った . 关の結果, 音圧レベルで $20 \mathrm{~dB}$ の 減音が見られた.Williams ら ${ }^{11)}$ は, 比較的高いマッハ数 でキャビティの角に設けたスロットからの吹出し・吸い込み

\footnotetext{
*1 C 2003 日本航空宇宙学会

平成 13 年 11 月 5 日原稿受理

$* 2$ 信州大学工学部環境機能工学科

$* 3$ 信州大学工学部機械システム工学科

${ }^{* 4}$ 長野県短期大学
}

によりキャビティ音を制御して，個々のモードまたは複数 モードの抑制に成功している．菊地ら ${ }^{12)}$ はスパン方向に並 ベた複数のピエゾフィルムに交互の逆位相電圧を加え，逆 位相同士の発生音の相殺により, 音圧レベルで約 $5 \mathrm{~dB}$ 低 減させている .さらに横川ら ${ }^{13)}$ はピエゾフィルムの代わり に薄型セラミックアクチュエータを用いて最高で $10 \mathrm{~dB}$ 程 度, 減音している。

キャビティ音の発生機構はフィードバック機構で説明さ れる.渦を伴ったせん断層はキャビティ下流端に衝突し，光 の衝突領域で攪乱 (圧力変動) を生じる. 圧力変動は上流 へフィードバックされ, キャビティ上流端ではく離したせ ん断層に局所的な渦度変動を誘起する．これにより，せん 断層に周期的な゙渦が形成され, 成長する.これらの過程に より, 流体的自励振動が生じる.

本実験ではノズル噴出口に突起物を設置してキャビティ 音の制御を試みる . キャビティを直接ノズル噴出口に取り 付けることで, キャビティ直前の境界層厚さが極薄くなり， キャビティ開口部のせん断層を解析上, 自由せん断層とし て近似できる利点がある．一方，噴流幅がキャビティ開口 長さと同じオーダーの大きさであるため, 上流が一樣流の 場合に比べ流れ場が複杂隹化してしまうが, 上流の消音を充 実させるため流量を抑える必要があり, 本研究では出口幅 が狭いノズルを採用した。

ノズル噴出口に突起物による発生音の制御はエッジトー ンの場合も利用され, 減音効果があることが明らかになっ ている ${ }^{14)}$. 本研究も同樣な制御法を採用し，ノズル噴出口 の長辺方向に三角形断面の突起物を設置した．この制御方 


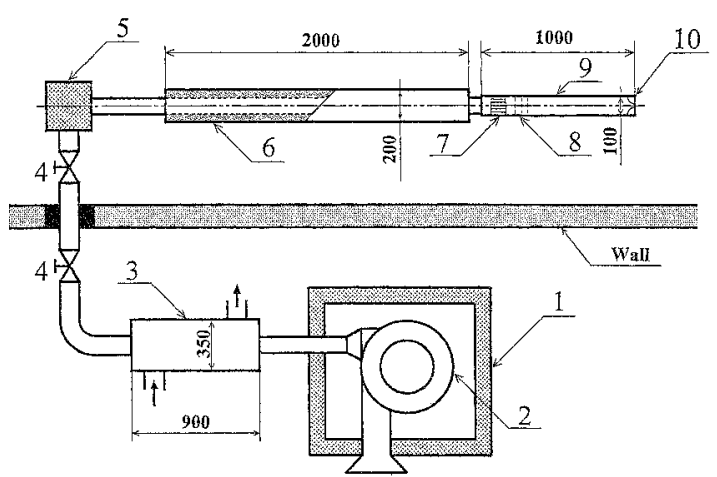

第 1 図 実験装置

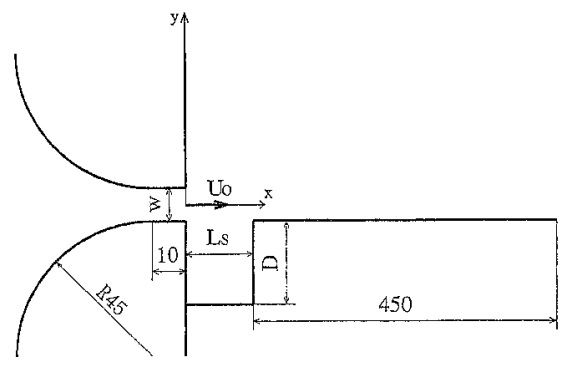

第 2 図 壁噴流およびキャビティ

法は極めて簡便な方法であり，例えば新幹線の車両間の隙 間や空調ダクトのつなぎ合わせでやむなくできるキャビティ 構造からの騒音低減などに工業的応用が期待できる．この 突起物によってはく離せん断層に形成される渦を長辺方向 に非一樣にし，フィードバックのループを弱めたり破壞す ることでキャビティ音の制御を試みた .

特に本研究では突起物による受動的制御について, 光の 発生音の抑制を定量的に評価し, 減音に十分な突起物の数 および高さの影響を調べること, および圧力変動分布と発 生音の関連性を調べることを目的とする．

\section{2. 実験装置および方法}

実験装置の概略を第 1 図に示す . 送風機からノズル出口 まではエッジ音の制御実験 ${ }^{14)}$ と同樣であるので詳しい説明 は光ちらを参照されたい，室外に設けられた収納箱 1 内に 設置した送風機 2 から送られた空気は, 冷却器 3 , 流量調 節弁 4 , 消音エルボ 5 , 消音ダクト 6 を通り整流チャンバ 9 内のハニカム 7 およびメッシュ 8 で整流された後，二次 元ノズル 10 から噴出する. 第 2 図にノズルおよびキャビ ティ形状を示す. 絞り比 10 のノズルは短辺 $w=10 \mathrm{~mm}$, 長辺 $h=150 \mathrm{~mm}$ の長方形断面の噴出口を持ち，噴出口の アスペクト比は 15 である . キャビティの上流側壁面は噴 流の長辺側出口と接し，キャビティの深さは $D=10 \mathrm{~mm}$ ， キャビティ上流側壁面 (噴流出口) からキャビティ下流側 壁面の距離は $L s=15 \mathrm{~mm}$ ，キャビティのスパン方向幅は $600 \mathrm{~mm}$ で光のスパン方向の端部は光のまま大気に開放し ている .キャビティ下流には長さ $450 \mathrm{~mm}$ の噴流壁面が取 り付けてある . 座標系は噴出口中心を座標原点にとり，噴

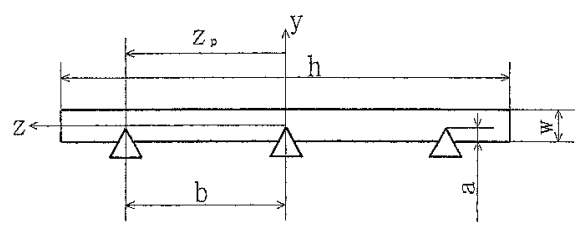

第 3 図噴出口に設置した制御用突起物

流方向を $x$, 噴出口短辺方向を $y$, 噴出口長辺方向を $z$ と した 。

実験において，噴流中心速度 $U_{0}=30 \mathrm{~m} / \mathrm{s}$ で，このと きキャビティ開口長さ $L s$ と噴流中心速度 $U_{0}$ に基づくレ イノルズ数 $R e=U_{0} L s / \nu$ は $3.0 \times 10^{4}$ である.上流が整 流された噴流でレイノルズ数も比較的低いことからキャビ ティ付近の流れは，もちろん組織的構造を持つ攂乱が存在 し得るが，ほぼ層流と思われる．ここで $\nu$ は動粘性係数 である. 第 3 図に攪乱源として噴出口に取り付けた三角形 突起物の位置と向きを示す. 突起物は厚さ $0.5 \mathrm{~mm}$ のアク リル製正三角形で，弚の頂角を $a \mathrm{~mm}$ 噴流側に突き出して キャビティ上流側壁面に取り付けられている．また突起物 の間隔は $b \mathrm{~mm}$, 取り付けた個数を $N P$ とした . 第 3 図に は $N P=3$ の場合の配置を示した . また突起物が 1 個の場 合，弚の中心からのスパン方向位置を $Z p$ とする．

流体音の音圧レベル SPL の測定には，座標原点である 噴出口中心から $y$ 方向に $150 \mathrm{~mm}$ のキャビティ上方にマイ クロフォンを設置し, 精密騒音計を用いて F 特性で測定し た。また，キャビティ下流壁面角に圧カセンサを取り付け， 兴の位置での圧力変動を測定した . 圧力センサの信号は直 流アンプで増幅され, 騒音計からの音圧変動信号と同樣に 周波数分析器によりスペクトル解析を行った .なお，送風 機を作動させない場合，つまり実験室からの音圧レベルは $57 \mathrm{~dB}$ ，キャビティを設置していない壁噴流の場合の音圧レ

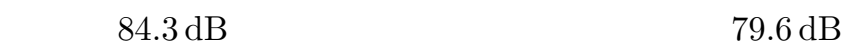
であった .これらの值の解釈はスペクトル解析結果のとこ ろで述べる。

実験条件として突起物高さ $a / w$ を $0 \sim 0.8$ ，また突起物 個数 $N P$ を $0 \sim 49$ の範囲で測定を行った . また $N P=1$ の 場合で, 突起物のスパン方向位置 $Z h / h$ を $0 \sim 0.5$ に変化 させ突起物の位置による影響も調べた .

\section{3. 実 験 結 果}

第 4 図に音圧変動の周波数スペクトルを示す . 縦軸は音 圧レベル SPL , 横軸は周波数である.比較のため図の縦軸， 横軸のスケールは同じにしてある . (a) は突起物を置かな い場合である. $500 \mathrm{~Hz}$ 以下に $80 \mathrm{~dB}$ 程度のピークがある . このピークも含め $10 \mathrm{~Hz}$ から $500 \mathrm{~Hz}$ のピーク付近のスペ クトル分布は壁噴流の場合 (f) でも見られ，さらにここで は示していないが自由噴流の場合にも同樣のスペクトル分 布が観察される．このことから，このピークおよび付近の 周波数帯の音は送風機などが起因する上流からのものと思 われる．乥こで， $1 \mathrm{kHz}$ 以上における判別可能なピーク周 

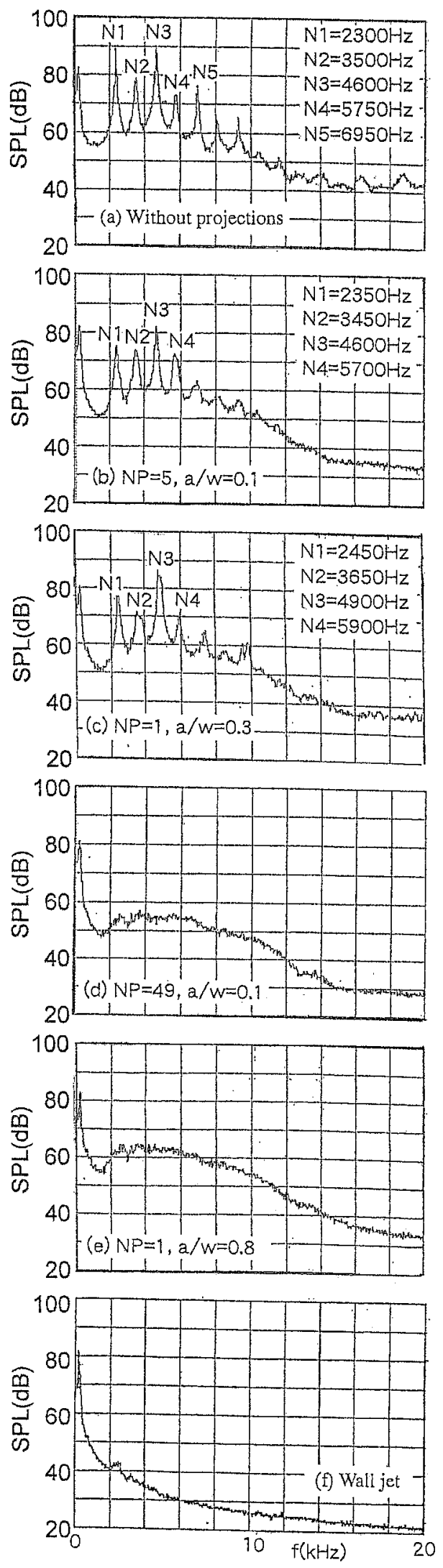

第 4 図 音圧変動の周波数スペクトル

波数を低い方から $N 1, N 2$ とした．この時，最大ピーク $N 3$ が $4600 \mathrm{~Hz}$ 付近にあらわれる. これらの無次元周波数 $S t_{N}=N L s / U$ は順に $1.15,1.75,2.3$ で, Rockwell ${ }^{15)}$

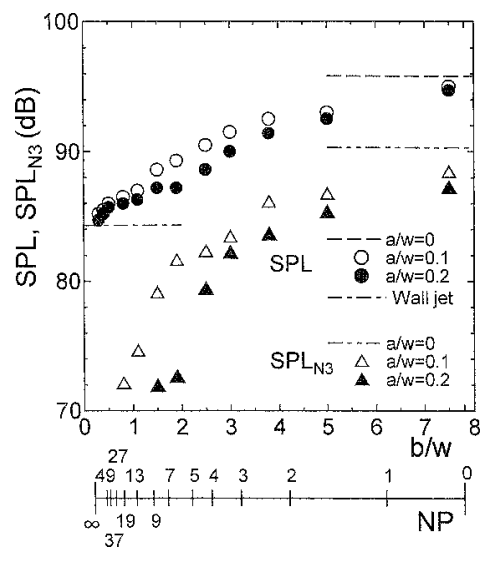

第 5 図 音圧レベル SPL と突起物の数 $N P$ との関係

の予測法によれば $N 1$ と $N 2$ はモード 2 とモード 3 にあ たる. Rockwell はモード 4 の周波数は計算していないが， $N 3$ がモード 4 であることは十分予想できる . 本実験条件 において周期的振動が見られた場合， $4600 \mathrm{~Hz}$ 付近の $N 3$ が常に最大ピークであったので, 今後この N3 を卓越周波 数とする.

(b) は突起物の個数 $N P=5$, 高さ $a / w=0.1$ で取り 付けた場合である.この時 $b / w=2.5$ である. 卓越周波数 の音圧レベルが明らかに減少しており, 他のピークも減少 している，特に $N 1$ の減音か顕著である. (c) は突起物数 $N P=1$, 高さ $a / w=0.3$ で取り付けた場合である. 卓越 周波数 N3 の音圧レベルは (b) の場合に比べ大きいが突起 物がない場合 (a) に対して減少しており，すべてのピーク 周波数においても (a) に対しては減少している. (d) は突起 物数 $N P=49$, 高さ $a / w=0.1$ で取り付けた場合である.

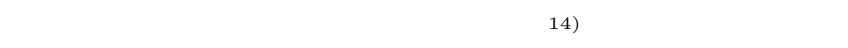
非常に多い $N P=49$ のときに卓越周波数の音圧が逆に増 加する現象が見られたが，キャビティの場合 $1 \mathrm{kHz}$ 以上の スペクトルにピークは観察されず, 流れの自励振動による 音の発生が抑制されていることが分かる．また，壁噴流の 場合と比べると $1 \mathrm{kHz}$ 以上の $55 \mathrm{~dB}$ 程度の連続スペクトル が存在することが分かる.この連続スペクトルは $3 \mathrm{kHz}$ 以 上で徐々に減少する．このノイズは高周波で骨らかに減衰 することから乱流騒音と考えられ，突起物から出る䚌乱が キャビティによるせん断層と干渉した結果発生した乱流騒 音と想像できる.(e) は突起物数 $N P=1$, 高さ $a / w=0.8$ で取り付けた場合である . 噴流出口の $80 \%$ に達する程度の 突起物高さになると，例え突起物数が 1 個でも，周期的流 体音の抑制に十分であることが分かる. $1 \mathrm{kHz}$ 以上の連続 スペクトルの最大音圧レベルは $65 \mathrm{~dB}$ 程度で , (d) の場合 より増加していることが分かる .

第 5 図に 20〜 $12500 \mathrm{~Hz}$ のほぼ可聴範囲全体の音圧レベ ル SPL (オーバーオール值) および卓越周波数 N 3 の音圧 レベル $\mathrm{SPL}_{N 3}$ と突起物の数 $N P$ との関係を示す. SPL を 見ると，破線で示している突起物を設置しない場合に対し， 突起物の個数 $N P$ か増加するとともに減少し, キャビティ 


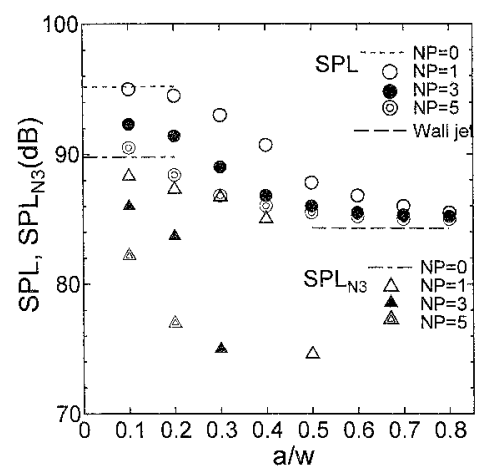

第 6 図 音圧レベル SPL と突起物の高さ $a$ との関係

を設置していない壁噴流の音圧レベル $\mathrm{SPL}=84.3 \mathrm{~dB}$ に近 付いていることが分かる $.1 .5 \leqq b / w \leqq 3.75$ の範囲では突 起物高さ $a / w$ が 0.1 よりも 0.2 の減音効果が大きいこと が分かるが, 他の範囲では光の差は比較的小さい. 卓越周 波数 $N 3$ の音圧レベル $\mathrm{SPL}_{N 3}$ を見ると, 突起物個数 $N P$ の増加による音圧レベルの減少がより明確にあらわれてい る.また, $1.5 \leqq b / w \leqq 3.75$ の範囲での突起物高さ $a / w$ の影響も全体の音圧レベル SPL より顕著で， 0.1 より 0.2 の減音効果が大きい .

このような減音効果はエッジトーンの場合 ${ }^{14)}$ でも見られ たが, $a / w=0.1$ の場合のように突起物が非常に低い場合 は, エッジトーンの減音効果がほとんど見られなかったの に対し，キャビティ音の減音効果が明確にあらわれている． $a / w=0.2$ の場合はキャビティにおいて $N P$ の増加ととも に徐々に減音効果が大きくなるのに対し，エッジトーンの 場合は $10 \mathrm{~dB}$ 程度の減音効果が $N P=1$ ですでにあらわれ， 乥れ以上の $N P$ では減音効果の変化が比較的少なかった。

第 6 図に音圧レベル $\mathrm{SPL}$ および $\mathrm{SPL}_{N 3}$ と突起物の高さ $a / w$ との関係を示す. 突起物の高さか増加すると SPL も $\mathrm{SPL}_{N 3}$ も減少していることが分かる.しかし, $N P=3$ の場合 $a / w \geqq 0.6, N P=5$ の場合 $a / w \geqq 0.5$ て暗騒音 とほぼ同じ $85 \mathrm{~dB}$ 付近で一定值になっていることが分かる . 第 5 図に示すように突起物個数 $N P$ を増加させていった場 合の SPL の最小值か滋 $85 \mathrm{~dB}$ であり，本実験の暗騒音下に おいては, 突起物の減音効果は突起物がない場合に対して $10 \mathrm{~dB}$ 程度の減音が見られる. $\mathrm{SPL}_{N 3}$ を見ると, 突起物の 高さの増加に伴い $N P=1$ の場合 $a / w=0.5, N P=3$ の場合 $a / w=0.3, N P=5$ の場合 $a / w=0.2$ で $75 \mathrm{~dB}$ 程度に急激に減少する.さらに突起物の高さを増すと $N 3$ のピークは見られなくなる.これは自励発振が止まったか， $1 \mathrm{kHz}$ から $3 \mathrm{kHz}$ にわたる $55 \mathrm{~dB}$ 程度の連続スペクトルの 中に埋もれてしまったためと思われる. $\mathrm{SPL}_{N 3}$ の変化を 見ると，流れの自励振動による音の発生か突起物により抑 制され，弚の効果は突起物の数または高さがある一定値を 超えると劇的にあらわれる.

第 7 図に無次元卓越音周波数 $S t_{N 3}=N 3 L s / U$ と突起 物の数 $N P$ との関係を示す. 突起物高さ $a / w=0.1$ のと きは卓越周波数は突起物の数 $N P$ には無関係でほぼ一定で

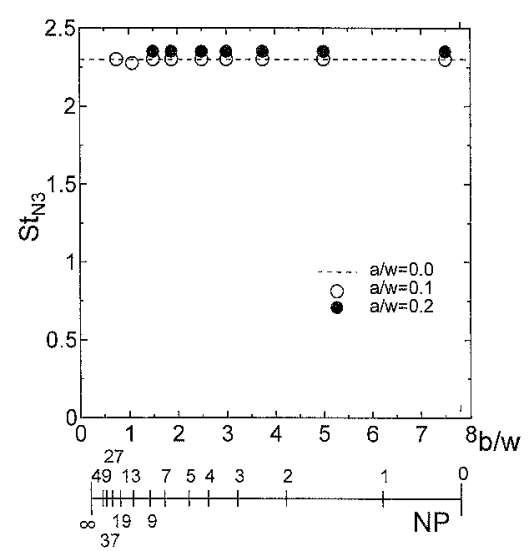

第 7 図 卓越音周波数 $S t_{N 3}$ と突起物の数 $N P$ との関係

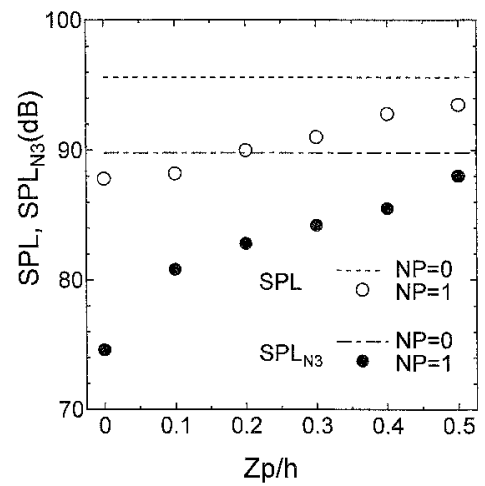

第 8 図 音圧レベル SPL と突起物のスパン方向位置 $Z p$ との関係

あることが分かる. 突起物高さ $a / w=0.2$ のときは卓越周 波数がわずかに増加したが，この場合も突起物の数 NPに は無関係でほぼ一定である。

第 8 図に音圧レベル SPL， $\mathrm{SPL}_{N 3}$ と突起物のスパン方 向位置 $Z p$ との関係を示す . 突起物は 1 個で, 兴のスパン 方向位置 $Z p$ は图中に示すように噴出口中心からの距離を とった .この時の $a / w=0.5$ である. 突起物が中心から離 れるとともに $\mathrm{SPL}, \mathrm{SPL}_{N 3}$ か増加し $Z p / h=0.5$,すな わち突起物中心か噴出口の短辺壁に重なるように取り付け た場合 , 突起物を取り付けない場合とほぼ同じ音圧レベル になる . $\mathrm{SPL}_{N 3}$ では, 中心に置く場合と光こから少しず れた場合 $Z p \geqq 0.1$ との差が大きく，非対称位置に突起物 を置くと急激に卓越周波数の音圧か増加することが分かる。

第 9 図に卓越周波数 $S t_{N 3}$ と突起物のスパン方向位置 $Z p$ の関係を示す. 単独突起物のスパン方向位置は卓越周波数 にほとんど影響しないことが分かる .

以上の結果から音の発生か突起物により制御できること が分かり，流れの自励振動が抑制されていることが示唆さ れた . 音が発生した場合の流れの振動を直接観察するため， また突起物間隔が非常に大きい場合において, 流れの振動 の二次元性がどのように変化するかを調べるため, キャビ ティ下流壁面角の圧力変動を測定した .

第 10 図は圧力変動の周波数スペクトルである . (a) は突 起物を設置しない場合で，この圧力変動スペクトルでも， 


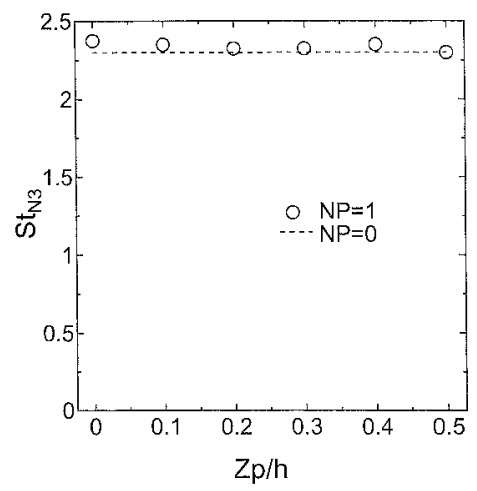

第 9 図 卓越周波数 $S t_{N 3}$ と突起物のスパン方向位置 $Z p$ の関係
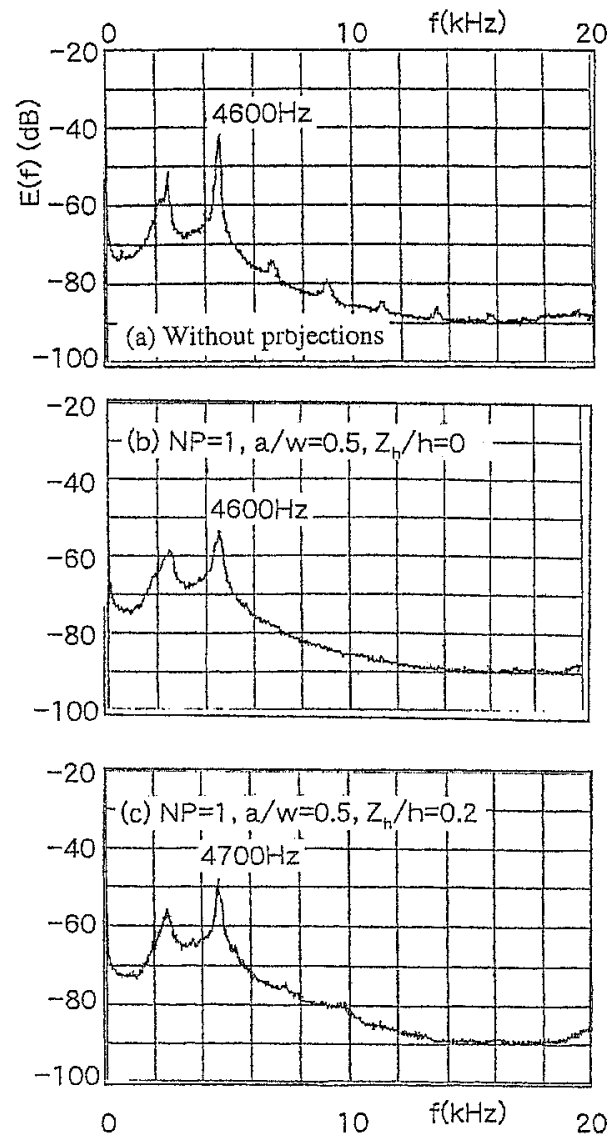

第 10 図 圧力变動の周波数スペクトル

音圧スペクトルで見られた卓越周波数 $N 3$ で最大ピークが 見られる.また音圧スペクトルにおける $N 1$ と同周波数で もピークが見られるが， $N 1$ と N3 の間に見られた $N 2$ の 周波数の音圧スペクトルピークは圧力変動スペクトルでは 見られない.これは, $N 2$ ピークが $N 1$ と $N 3$ に対して比 較的弱いため，暗騒音に埋没したためと思われる . (b) と (c) は突起物を一つ設置した場合で, 弚のスパン方向位置は $Z p=0$ ，つまり噴出口中心である . (b) は圧力センサのス パン方向位置 $Z h=0$, つまり突起物の直下流の位置にお ける圧力変動スペクトルで, 2 個のピーク值がともに , 突 起物がない場合に比へ小さいことが分かる . (c) は (b) と同

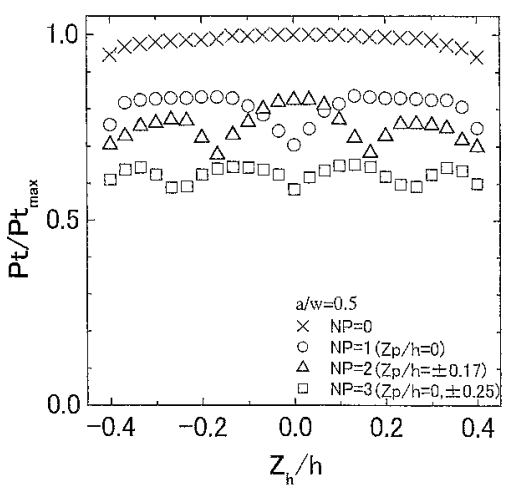

第 11 図 卓越周波数の圧力变動振幅のスパン方向分布

じ条件での突起物の直下流でない位置 $Z h / h=0.2$ での圧 力変動スペクトルで, この場合 $4600 \mathrm{~Hz}$ と $2300 \mathrm{~Hz}$ 付近の ピーク值が (b) に比べ大きくなっている．しかし，突起物 がない場合 (a)のピーク值よりは小さいことが分かる .

第 11 図に圧力変動における卓越周波数のスペクトル強 度 Pt のスパン方向分布を示す.縦軸は突起物がない場合 の最大スペクトル強度 $P t_{\max }$ で無次元化している. 突起 物個数 NP の増加とともに圧力変動が全体的に減少してい る. また突起物直下流では圧力変動がどの位置でも減少し ていることが分かる $. N P=1$ の場合, 突起物直下流の 圧力変動と关こから十分離れた位置での圧力変動との差が $15 \%$ 程度である. また突起物直下流から離れた領域，例え ば $1.5 \leqq Z h / h \leqq 3.5$ では圧力変動がほぼ一定になる.こ れは, 突起物直下流以外の流れがまだ二次元性を保ってい る可能性を示している.一般的にフィードバック系による 流れの自励振動は, 外部擤乱などで流れの対称性 (本研究 では二次元性) を崩すことにより抑制されると言われてい る. しかし単独突起物の突起間隔 $b / w \geqq 5$ の場合では, 下 流の広範囲において圧力変動振幅の一樣性を保ちながら流 れの振動および音の発生か抑制されていることから，ただ 単に流れ一樣性の崩壊による制御とは違う物理的機構が存 在している可能性がある．もちろん，このことを解明する には圧力変動の位相情報, さらには速度変動を詳しく見る 必要がある。

圧力変動が突起物直下流において局所的に減少し，かつ スパン方向全体にわたる平均的な減少は, エッジトーンの 制御 ${ }^{14)}$ でも見られる.このことはフィードバックによる流 れの自励振動現象に対しての比較的広い間隔の突起物によ る制御が, 同じ物理機構て働いていることか推測される .こ のような制御の流体力学的解釈には位相関係などを含めた 十分な流れ場および音場の情報が不可欠であり，流速の測 定実験や数值解析などのさらなる研究が必要であると思わ れる。
4. 結
論

噴流・キャビティ系流れにおいて，噴出口に突起物を設 置することにより，流体音の制御を試みた . 得られた結果 は以下の通りである . 
1) 噴出口に突起物を設置することにより，流体音が制御 されることが分かった .

2) 減音の効果は突起物の間隔が狭くなるにつれ増加す るが, $a / w=0.1$ の場合 $b / w \leqq 0.8, a / w=0.2$ の場合 $b / w \leqq 2$ で, $\mathrm{F}$ 特性による音圧レベルは $10 \mathrm{~dB}$ ，ピーク音 圧で $15 \mathrm{~dB}$ 以上の減音効果があった .

3) 突起物による制御では発生音の周波数に影響を及ぼさ ない。

4) $N P=1$ の場合, 突起物の設置位置 $Z p / h$ が SPL と $\mathrm{SPL}_{N 3}$ に影響し $Z p / h=0$ で咸音効果が最大になること が分かった. $Z p / h$ の值が増加すると $\mathrm{SPL}, \mathrm{SPL}_{N 3}$ は増 加する。

5) キャビティ下流壁面角の圧力変動の卓越周波数スペク 卜ル強度 $P t / P t_{\max }$ のスパン方向分布において, 突起物の 設置位置の直下流で $P t / P t_{\max }$ の值が極小值を持った . ま た $N P=1$ の場合，突起物の直下流から離れた位置では圧 力変動がほぼ一定で, 圧力変動の一樣性が保持されている ことが分かった .

\section{参 考 文 献}

1) Elder, S. A., Farabee, T. M. and DeMetz, F. C.: Mechanisms of Flow-Excited Cavity Tones at Low Mach Number, J. Acoust. Soc. Am., 72 (1982), pp. 532-549.

2) Sarohia, V.: Experimental Investigation of Oscillations in Flows over Shallow Cavities, AIAA J., 15 (1977), pp. 984991.

3) Ronneberger, D.: The Dynamics of Shearing Flow over a
Cavity - A Visual Study Related to the Acoustic Impedance of Small Orifices, J. Sound Vib., 71 (1980), pp. 565-581.

4) Nelson, P. A., Halliwell, N. A. and Doak, P. E.: Fluid Dynamics of a Flow Excited Resonance, Part I: Experiment, J. Sound Vib., 78 (1981), pp. 15-38.

5) East, L. F.: Aerodynamically Induced Resonance in Rectangular Cavities, J. Sound Vib., 3 (1966), pp. 277-287.

6）槙 浩幸, 藤田 肇, 丸田芳幸, 松本芳幸: 流体騒音発生機構の 実験的研究，機講論，No. 96-1, 1996, pp. 57-58.

7) Rockwell, D. O. and Naudascher, E.: Review-Self-Sustained Oscillations of Flow Past Cavities, Trans. ASME, J. Fluids Eng., 100 (1978), pp. 152-165.

8) Rockwell, D. O. and Naudascher, E.: Self-Sustained Oscillations of Impinging Free Shear Layers, Annu. Rev. Fluid Mech., 11 (1979), pp. 67-94.

9) 御法川学, 丸田芳幸 : キャビティ音の周波数制御, 第 44 回応用 力学連合講演会, 1995 , pp. 313-314

10) Cattafesta III, L. N., Garg, S., Choudhari, M. and Li, F.: Active Control of Flow-Induced Cavity Resonance, AIAA Paper 97-1804, 1997, pp. 1-12.

11) Williams, D. R., Fabris, D., Iwanki, K. and Morrow, J.: Closed-Loop Control in Cavities with Unsteady Bleed Forcing, AIAA Paper 2000-0470, 2000, pp. 1-8.

12) 菊地 聡, 福西 祐, 太田黑俊夫:ピエゾフィルムを用いたキャビ ティ騒音の能動制御 . 日本流体力学会誌 , 19 (2000), pp. 200-206.

13) 横川 滾, 福西 祐, 菊地 聡: 薄型セラミックアクチュエータ によるキャビティ上の流れと発生音の動的制御，日本機械学会論 文集 B 編，67 (2001), pp. 2218-2225.

14）池田敏彦, 徳永淳一，土屋良明，長澤忠延，掘越長次：エッジ音 の制御に関する実験研究，日本航空宇宙学会誌，45 (1997), pp. 404-410.

15) Rockwell, D. O.: Prediction of Oscillation Frequencies for Unstable Flow Past Cavities, Trans. ASME, J. Fluids Eng., 99 (1977), pp. 294-300. 